Artikel Penelitian

\title{
Respon Glikemik dan Aktivitas Antioksidan Nasi Yang Dimasak Menggunakan Campuran Kunyit (Curcuma longa Linn.) dan Kayu Manis (Cinnamomum sp)
}

\author{
Glycemic Response and Antioxidant Activity of Rice Cooked with Combination of Turmeric (Curcuma \\ longa Linn.) and Cinnamon (Cinnamomum sp). \\ Samsu Udayana Nurdin ${ }^{1,2 \star}$, Yofita Sulfiana Sundari ${ }^{1}$, Novita Herdiana ${ }^{1}$, Fibra Nurainy ${ }^{1}$, Asep Sukohar ${ }^{3}$ \\ ${ }^{1} J u r u s a n$ Teknologi Hasil Pertanian Fakultas Pertanian Universitas Lampung, Bandar Lampung \\ ${ }^{2}$ Pusat Penelitian dan Pengembangan Gizi, Kesehatan dan Herbal Universitas Lampung, Bandar Lampung \\ ${ }^{3}$ Fakultas Kedokteran Universitas Lampung, Bandar Lampung \\ *Korespondensi dengan penulis (samsu.udayana@fp.unila.ac.id). \\ Artikel ini dikirim pada tanggal 24 Mei 2018 dan dinyatakan diterima tanggal 30 Agustus 2018. Artikel ini juga dipublikasi secara online melalui \\ https://ejournal2.undip.ac.id/index.php/jatp. Hak cipta dilindungi undang-undang. Dilarang diperbanyak untuk tujuan komersial. \\ Diproduksi oleh Indonesian Food Technologists $®(2018$
}

\begin{abstract}
Abstrak
Penurunan daya cerna pati nasi merupakan cara yang menjanjikan untuk menurunkan efek hiperglikemia nasi. Beberapa penelitian menunjukkan bahwa kunyit (Curcuma longa Linn) dan kayu manis (Cinnamomum sp) dapat menurunkan daya cerna pati karena kandungan senyawa penoliknya. Penelitian ini bertujuan untuk mempelajari apakah kunyit, kayu manis atau kombinasinya memiliki kemampuan untuk menurunkan daya cerna pati atau meningkatkan aktivitas antioksidan nasi putih. Kombinasi 3 dan $0 \mathrm{~g}$ (C1), 2 dan $1 \mathrm{~g}$ (C2), 1 dan $2 \mathrm{~g}$ (C3), atau 0 dan $3 \mathrm{~g}$ (C4) masing-masing untuk kunyit dan kayu manis digunakan untuk memasak nasi putih. Hasil penelitian menunjukkan bahwa penggunaan kunyit dan kayu manis untuk memasak nasi tidak mempengaruhi daya cerna pati, aktivitas antioksidan, dan kadar total penolik nasi tetapi mempengaruhi penerimaan konsumen terhadap nasi. Formula terbaik adalah kombinasi antara $2 \mathrm{~g}$ kunyit dan $1 \mathrm{~g}$ kayu manis (C2) dimana nasi yang dimasak dengan tambahan campuran ini memiliki karakteristik sebagai berikut: tingkat hidrolisis pati 3,99 kali, aktivitas antioksidan $42,03 \%$, kadar total penol 117,18 ppm (GAE), dan oleh konsumen dianggap layak sebagai makanan pokok. Kesimpulannya adalah nasi yang dimasak dengan formula C2 memiliki respon glikemik yang tidak berbeda dengan nasi biasa.
\end{abstract}

Kata kunci: Kunyit; kayu manis; respon glikemik; penol; daya cerna pati.

\section{Abstract}

Reducing of starch digestibility of the rice is one of promising strategies to reduce hyperglycemic effect of the rice. Some research indicate turmeric (Curcuma longa Linn) and cinnamon (Cinnamomum $\mathrm{sp}$ ) reduced starch digestibility due to their phenolic content. This research was aimed to study whether turmeric, cinnamon and their combination have potentiality to reduce starch digestibility or increase antioxidant activity of white rice. Combination of 3 and $0 g$ (C1), 2 and $1 \mathrm{~g}$ (C2), 1 and $2 g$ (C3), 0 and $3 g$ (C4) turmeric and cinnamon were used for cooking white rice. The results showed that the addition of turmeric and cinnamon for cooking of rice had no effect on the level of starch hydrolysis, antioxidant activity and phenolic content of rice but significantly affected the consumer acceptance of the rice. The best formula was combination of $2 \mathrm{~g}$ of turmeric and $1 \mathrm{~g}$ of cinnamon (C2) where the rice cooked by adding this formula had characteristics as follows= starch hydrolysis level was 3.989 fold, antioxidant activity was $42.03 \%$, total phenol was $117.18 \mathrm{ppm}$ (GAE). Consumers considered that the rice was suitable for staple food. However, no. difference on the glycemic respons was found. As conclusion, addition of turmeric, cinnamon or their combination for cooking of rice was unable to decrease starch digestibility and increase antioxidant activity of the rice.

Keyword : turmeric, cinnamon, glycemic response, phenol, starch digestibility

\section{Pendahuluan}

Pada penderita diabetes, homeostasis gula darah terganggu disebabkan ketidakmampuan tubuh menjaga kadar gula darah karena produksi insulin yang rendah atau inefisiensi kerja insulin. Akibatnya glukosa yang berasal dari makanan lambat digunakan dan kadarnya terus meningkat dalam darah seiring dengan meningkatnya asupan (Anderson et al., 2006). Membatasi konsumsi pangan sumber glukosa merupakan pendekatan penting dalam pengelolaan penyakit diabetes. Pembatasan ini memerlukan tingkat kedisiplinan yang tinggi dan sering menyulitkan penderita sehingga sering mengalami kegagalan perawatan (Dyson, 2015) .

Nasi merupakan makanan yang memberikan kontribusi penting pada terjadinya penyakit diabetes $(\mathrm{Hu}$ et al., 2013). Nasi mengandung pati yang tinggi yang melalui proses pencernaan akan diserap tubuh dalam bentuk glukosa. Karena itu konsumsi nasi dalam jumlah banyak dan jangka waktu lama dapat meningkatkan resiko penyakit diabetes (Riccardi et al., 2005; Hu et al., 2013). Bahkan pada penderita diabetes asupan nasi 
harus terkontrol dengan memperhatikan jumlah dan waktu konsumsi (Dyson, 2015).

Modifikasi pati pada nasi dapat menghasilkan pati resisten yang tidak terhidrolisis selama proses pencernaan. Senyawa penol adalah satu zat yang dapat bereaksi dengan pati yang menyebabkan penurunan daya cerna pati (Zhu, 2015). Selain dengan pati, senyawa penol juga dapat bereaksi dengan protein membentuk senyawa yang lebih komplek (PerezGregorio dan Simal-Gandara, 2017). Karena enzim yang terlibat pada pencernaan pati tersusun dari protein maka diduga senyawa penol juga dapat mengganggu aktivitas enzim-enzim tersebut. Selain itu beberapa senyawa penolik bersifat sebagai antioksidan yang diduga dapat berperan penting pada pencegahan perkembangan dan komplikasi diabetes (Ghosh et al., 2018; Polce et al., 2018).

Kayu manis dan kunyit kaya akan senyawa penolik dan diketahui memiliki efek penghambatan terhadap kerja enzim glukosidase dan memiliki aktivitas antioksidan (Zheng et al., 2018; Wojcik et al., 2018; Talaei et al., 2017). Kedua jenis rempah-rempah ini telah sering digunakan oleh masyarakat Indonesia untuk bumbu memasak nasi. Penelitian ini menganalisis apakah penggunaan campuran kunyit dan kayu manis dapat menurunkan daya cerna pati dan meningkatkan aktivitas antioksidan nasi yang dihasilkan. Manfaat dari penelitian ini adalah dapat membuka pengetahuan pada masyarakat mengenai upaya penurunan daya cerna dan peningkatan aktivitas antioksidan pada nasi.

\section{Materi dan Metode \\ Materi}

Bahan utama yang digunakan yaitu kunyit dan kayu manis yang diperoleh di pasar tradisional Jatimulyo, Lampung Selatan dan beras dengan varietas Ciherang yang berasal dari daerah Lampung Timur. Untuk menentukan tingkat hidrolisis pati digunakan enzim a-amilase dari Aspergilus Oryzae (Sigma Aldrich, US). Bahan yang digunakan untuk analisis antara lain Dinitro Salisilat (DNS) (Sigma Aldrich, US), Nametabisulfit (Merck KGaA, Jerman), $\mathrm{NaOH}$ (Merck KGaA, Jerman), Kalsium Natrium Tartrat Tetrahidrat (Sigma Aldrich, US), fenol, folin ciocalteu (Merck KGaA, Jerman), Natrium Karbonat $\left(\mathrm{Na}_{2} \mathrm{CO}_{3}\right)$ (Merck KGaA, Jerman), ethanol absolute (Merck KGaA, Jerman), DPPH (1,1-difenil-2-pikrilhidrazil) (Yunphos, China), dan kertas saring.

Alat yang digunakan pada penelitian ini antara lain rice cooker (Maspion), loyang, blender merk Miyako, neraca analitik, oven, ayakan (Endecotls Ltd., UK), spectrophotometer blood glucose test meter (ACCU CHEK Active, Australia).

\section{Metode}

Penelitian ini dilakukan dalam dua tahap. Tahap pertama dilakukan untuk mencari formula campuran kunyit dan kayu manis yang dapat menurunkan derajat hidrolisis pati dan meningkatkan aktivitas antioksidan nasi secara optimal dan nasi yang dihasilkan layak untuk dijadikan sebagai makanan pokok. Selanjutnya formula terbaik dengan kriteria tersebut digunakan untuk memasak nasi dan nasi yang dihasilkan diuji respon glikemiknya dan dibandingkan dengan nasi biasa (Tahap kedua).

Penelitian pertama menggunakan Rancangan Acak Kelompok Lengkap (RAKL) non faktorial dengan tiga kali ulangan. Penelitian ini dilakukan dengan lima perlakuan yaitu formula yang terdiri dari bubuk kunyit 3 $\mathrm{g}$ (C1), kombinasi bubuk kunyit $2 \mathrm{~g}$ dengan bubuk kayu manis $1 \mathrm{~g}(\mathrm{C} 2)$, kombinasi kunyit $1 \mathrm{~g}$ dengan bubuk kayu manis $2 \mathrm{~g}(\mathrm{C} 3)$, bubuk kayu manis $3 \mathrm{~g}(\mathrm{C} 4)$ dan kontrol yaitu tanpa menggunakan kunyit atau kayu manis (C5). Pada penelitian kedua, nasi terbaik dari penelitian pertama dibandingkan dengan nasi biasa atau kontrol dengan cara diujikan pada 10 orang responden sehat. Penelitian ini telah mendapat persetujuan dari Komite Etik Penelitian Kesehatan Fakultas Kedokteran Universitas Lampung dengan nomor 1974/UN26/8/DL/2017.

\section{Persiapan Bahan untuk Formulasi Campuran Herbal}

Pengeringan kunyit diawali dengan pemilihan rimpang kunyit yang tua dan segar. Kunyit dicuci hingga bersih dan kemudian diiris tipis-tipis. Kunyit dikeringkan dengan menggunakan oven pada suhu $40^{\circ} \mathrm{C}$ selama dua hari, sedangkan untuk kayu manis tidak dikeringkan karena sudah tersedia dalam bentuk kering. Kunyit dan kayu manis selanjutnya dihancurkan menggunakan blender sehingga diperoleh serbuk kering kunyit dan kayu manis yang kasar (tidak halus), kemudian diayak untuk menyeragamkan ukurannya yaitu serbuk lolos ayakan 10 mesh tapi tidak lolos ayakan 20 mesh. Serbuk rempah selanjutnya dicampurkan sesuai dengan perlakuan dengan berat total $3 \mathrm{~g}$ dan dimasukkan ke dalam kantong kertas saring yang dipotong dengan ukuran seragam. Kantong yang telah diisi dengan campuran rempah kemudian ditutup menggunakan sealer.

\section{Pemasakan Nasi}

Pemasakan nasi dilakukan dengan menggunakan rice cooker. Air sebanyak $400 \mathrm{ml}$ dimasukkan kedalam rice cooker dan ditunggu hingga mendidih, kemudian kantong berisi rempah dimasukkan kedalam rice cooker, setelah 5 menit kemudian dimasukkan beras sebanyak $200 \mathrm{~g}$ yang telah dicuci. Pemasakan selesai jika rice cooker menunjukan bahwa pemasakkan telah selesai.

\section{Pengamatan}

Parameter yang diamati pada penelitian ini adalah derajat hidrolisis (daya cerna) pati (Muchtadi et al., 1989), aktivitas antioksidan dengan metode DPPH, serta total fenol (Ismail et al., 2012). Penerimaan konsumen terhadap nasi yang dihasilkan diuji menggunakan metode central location test (Resurreccion, 1998) pada 5 lokasi yang berbeda dengan melibatkan 119 panelis yang terdiri atas dosen, karyawan dan mahasiswa Universitas Lampung. Selanjutnya nasi yang memiliki daya cerna pati terendah dan aktivitas antioksidan tertinggi serta paling dianggap layak sebagai makanan 
pokok oleh konsumen diuji respon glikemiknya pada responden yang sehat.

\section{Pengukuran Respon Glikemik}

Pengukuran respon glikemik diawali dengan tahap seleksi calon responden. Calon responden adalah mahasiswa Universitas Lampung berjumlah 10 orang, laki-laki dan perempuan, berumur 18-25 tahun, memiliki Indeks Massa Tubuh (IMT) normal antara 18,5-22,9 $\mathrm{kg} / \mathrm{m}^{2}$ dan dalam keadaan sehat, tidak merokok dan meminum minuman beralkohol, dan tidak memiliki riwayat diabetes. Pengukuran respon glikemik nasi dengan menggunakan metode El (1999). Dalam tahap ini sebelum pengukuran respon glikemik responden diminta menjalani puasa penuh (overnight fasting), kecuali air minum selama 10 jam. Sebelum pemberian pangan uji, kadar glukosa darah responden diuji untuk mengetahui kadar gula puasa. Kemudian responden diminta mengkonsumsi pangan uji dengan kandungan karbohidrat sebanyak $40 \mathrm{~g}$ dengan memperhitungkan kadar air yang terkandung pada bahan. Selanjutnya sampel darah responden diambil kembali pada menit ke30, 60, 90, dan 120 setelah responden selesai makan pangan uji. Pengukuran glukosa darah menggunakan glucose meter. Selama pengambilan darah berlangsung, responden bersifat santai dan tidak boleh melakukan pekerjaan berat. Pemberian pangan uji dilakukan dengan jeda empat hari untuk masing-masing pangan. Kadar glukosa darah (setiap waktu pengambilan darah) yang telah diperoleh kemudian dirata-rata dari seluruh responden. Kadar glukosa darah yang telah diperoleh kemudian disajikan dalam bentuk grafik antara kadar gula (sumbu Y) dan waktu pengambilan darah (sumbu $X)$. Respon glikemik nasi ditentukan dengan menghitung luas area dibawah kurva. Respon glikemik didefinisikan sebagai luas area di bawah kurva kadar gula darah setelah mengonsumsi nasi setara $40 \mathrm{~g}$ karbohidrat.

\section{Analisis Statistik}

Percobaan disusun dalam Rancangan Acak Kelompok Lengkap (RAKL) dengan 3 ulangan. Data yang diperoleh dianalisis dengan analisis ragam (ANOVA) untuk mendapatkan penduga ragam galat dan perbedaan antar perlakuan. Untuk mengetahui perbedaan antar perlakuan, data di uji lebih lanjut dengan uji beda nyata terkecil (BNT) pada taraf nyata 1 dan $5 \%$.

\section{Hasil dan Pembahasan}

\section{Tingkat Hidrolisis Pati Nasi}

Nasi merupakan bahan pokok yang memiliki kandungan pati yang tinggi. Sebagai makanan pokok, nasi memberikan kontribusi yang signifikan terhadap peningkatan gula darah sehingga menjadi salah satu faktor resiko terjadinya penyakit diabetes ( $\mathrm{Hu}$ et al., 2013). Penurunan daya cerna pati nasi merupakan alternatif penting yang dapat digunakan untuk mencegah terjadinya hiperglikemia. Penurunan ini dapat dilakukan dengan cara memodifikasi pati sehingga tidak dikenali oleh enzim pencernaan atau menghambat kerja enzim yang terlibat pada pencernaan pati. Berbagai komponen bioaktif tanaman diketahui dapat bereaksi dengan pati sehingga menjadi resisten terhadap pencernaan atau menghambat kerja enzim pencernaan sehingga enzim tersebut gagal mencerna pati (Zhu, 2015).

Pada penelitian ini, penggunaan campuran kunyit dan kayu manis pada proses pemasakan nasi tidak dapat menurunkan daya cerna pati nasi (Figur 1). Kadar gula yang dibebaskan setelah tepung nasi yang dimasak dengan campuran herbal $(\mathrm{C} 1, \mathrm{C} 2, \mathrm{C} 3$ dan $\mathrm{C} 4)$ diinkubasi dengan enzim alfa amilase selama 60 menit tidak berbeda nyata dengan tepung nasi biasa (C5). Diduga kadar senyawa bioaktif khususnya senyawa fenolik yang terekstrak dari campuran kunyit dan kayu manis kadarnya terlalu rendah untuk dapat menghambat aktivitas enzim alpha amilase (Marmouzi et al., 2017). .

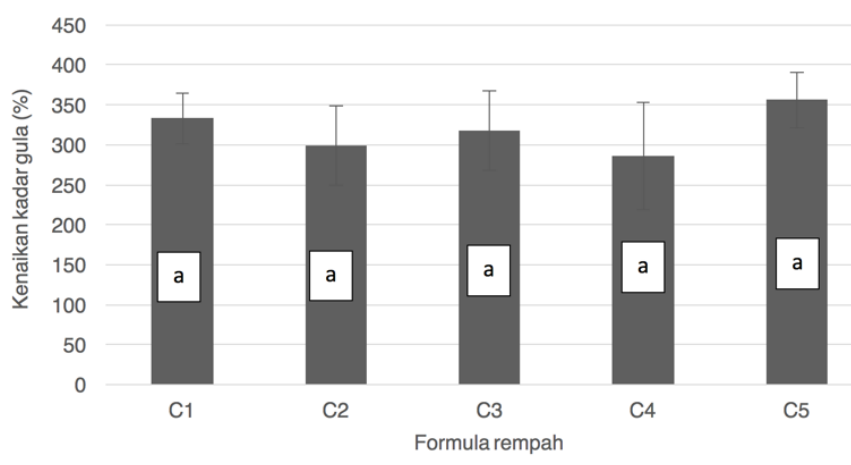

Figur 1. Pengaruh perlakuan terhadap tingkat hidrolisis pati nasi yang diinkubasi selama 60 menit. Nilai tengah yang diikuti dengan huruf yang sama dinyatakan tidak berbeda nyata menurut uji BNT 5\% . C1 = $3 \mathrm{~g}$ kunyit dan $0 \mathrm{~g}$ kayu manis; C2 $=2 \mathrm{~g}$ kunyit dan $1 \mathrm{~g}$ kayu manis; $\mathrm{C} 3=1 \mathrm{~g}$ kunyit dan 2 gram kayu manis; $\mathrm{C} 4=0 \mathrm{~g}$ kunyit dan $3 \mathrm{~g}$ kayu manis; $\mathrm{C} 5=$ kontrol

Pada pengujian tingkat hidrolisis pati ini digunakan satu jenis enzim yaitu alpha amilase. Berbagai penelitian menunjukkan bahwa tingkat penghambatan senyawa penolik terhadap enzim alpha amilase tergantung pada dosis dan sumber senyawa penolik yang digunakan (Kalita et al., 2018; Marmouzi et al., 2017; Gondi dan Prasada, 2015). Senyawa penolik dari Moroccan Oat memiliki $\mathrm{IC}_{50}$ terhadap enzim alpha amilase antara 723,1 hingga 1027,14 ppm, tergantung pada varietasnya (Marmouzi et al., 2017). Sementara itu, senyawa penolik dari kentang dan kulit mangga memiliki $\mathrm{IC}_{50}$ terhadap enzim alpha amilase yang jauh lebih rendah yaitu masing-masing 25 ppm (Kalita et al., 2018) dan 4,0 ppm (Gondi dan Prasada, 2015). Pada penelitian ini, untuk menghidrolis pati nasi menggunakan enzim alpha amilase, nasi kering dicampurkan dengan buffer pospat yang mengandung enzim dengan perbandingan 1 dan 9. Karena kandungan senya penolik nasi berkisar antara 99,41(C5) hingga 119,03 ppm (C4) (Figur 4), maka setelah dicampurkan dengan buffer pospat yang mengandung enzim maka konsentrasi total penolnya berkisar antara 9,94 hingga 11,90 ppm. Konsentrasi senyawa penolik pada nasi akibat penambahan campuran kunyit dan kayu manis ini diduga belum mampu meningkatkan penghambatan kerja enzim alpa amilase yang digunakan untuk menghidrolis pati nasi. 
Aktivitas Antioksidan Nasi

Sebagaimana pengaruh terhadap tingkat

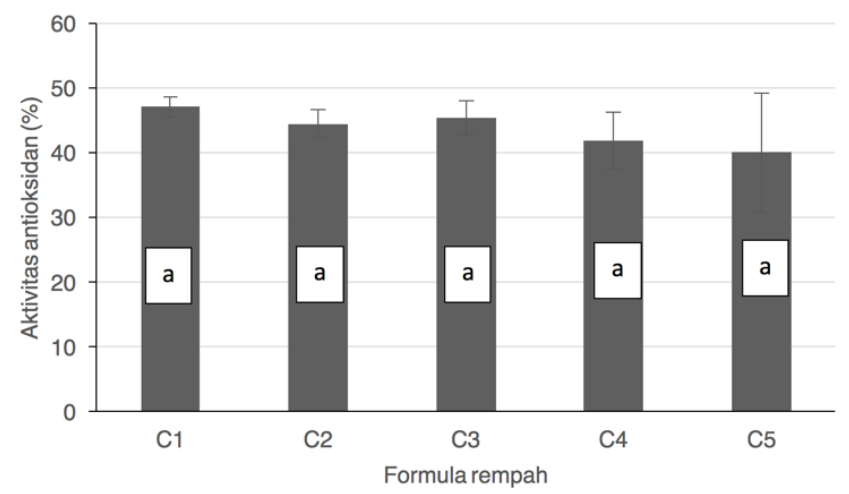

Figur 2. Pengaruh perlakuan terhadap aktivitas antioksidan nasi. Nilai tengah yang diikuti dengan huruf yang sama dinyatakan tidak berbeda nyata menurut uji BNT 5\% . C1 $=3 \mathrm{~g}$ kunyit dan $0 \mathrm{~g}$ kayu manis; $\mathrm{C} 2=2 \mathrm{~g}$ kunyit dan $1 \mathrm{~g}$ kayu manis; C3 = $1 \mathrm{~g}$ kunyit dan 2 gram kayu manis; C4 = $0 \mathrm{~g}$ kunyit dan 3 g kayu manis; $\mathrm{C} 5$ = kontrol

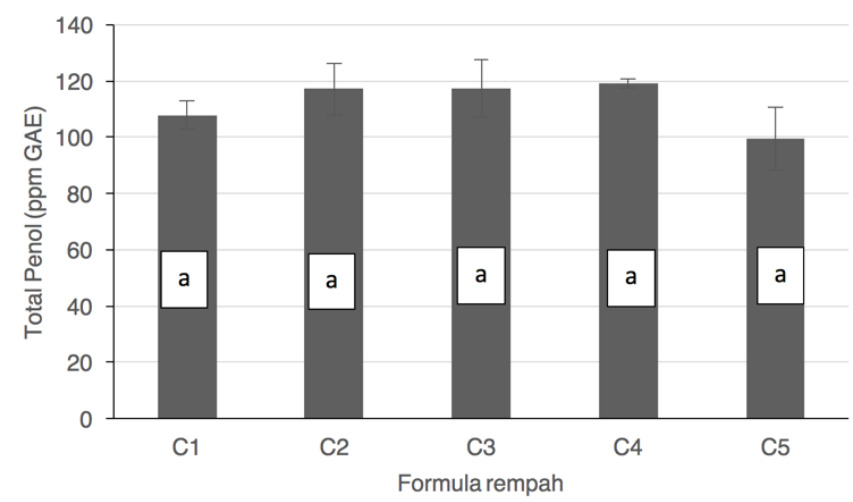

Figur 3. Pengaruh perlakuan terhadap total fenol nasi. Nilai tengah yang diikuti dengan huruf yang sama dinyatakan tidak berbeda nyata menurut uji BNT $5 \% . \mathrm{C} 1=3 \mathrm{~g}$ kunyit dan $0 \mathrm{~g}$ kayu manis; $\mathrm{C} 2=2 \mathrm{~g}$ kunyit dan $1 \mathrm{~g}$ kayu manis; $\mathrm{C} 3=1 \mathrm{~g}$ kunyit dan 2 gram kayu manis; C4 = 0 g kunyit dan $3 \mathrm{~g}$ kayu manis; C5 $=$ kontrol

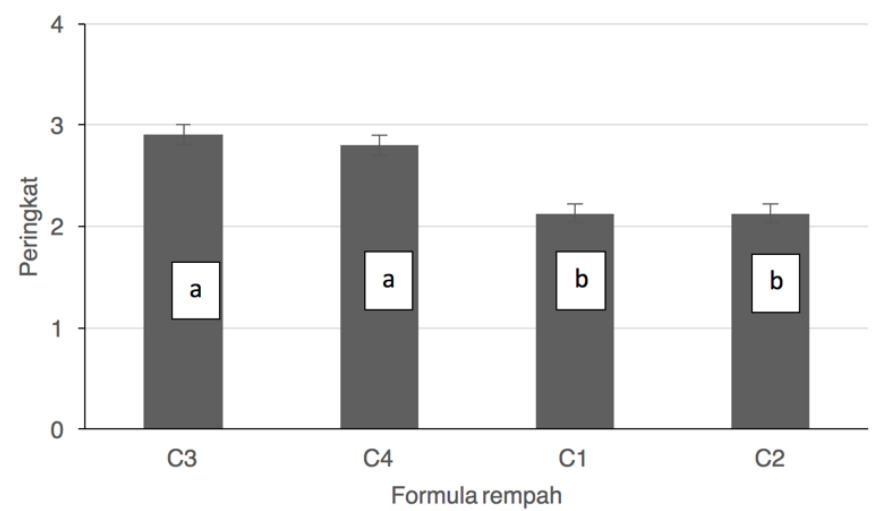

Figur 4. Pengaruh komposisi rempah yang digunakan dalam pemasakan nasi terhadap peringkatan kelayakan menurut panelis. Nilai tengah yang diikuti dengan huruf yang sama dinyatakan tidak berbeda nyata menurut uji BNT 5\%. C1 = 3 gram kunyit. 0 gram kayu manis; C2 = 2 gram kunyit, 1 gram kayu manis; C3 = 1 gram kunyit, 2 gram kayu manis; C4 = 0 gram kunyit, 3 gram kayu manis; C5 = Control hidrolisis pati nasi, penambahan campuran kunyit dan kayu manis juga tidak dapat meningkatkan aktivitas antioksidan nasi biasa (kontrol) atau yang dimasak dengan penambahan kunyit dan kayu manis berkisar antara 40,046\% (C5) hingga 47,047\% (C1). Hasil ini juga merupakan bukti bahwa nasi biasa juga mengandung antioksidan sebagaimana telah dilaporkan oleh peneliti sebelumnya (Walter dan Marchesan, 2011; Goufo dan Tridande, 2014; Shao et al., 2014).

Senyawa penolik memberikan kontribusi penting pada kapasitas antioksidan nasi/beras (Ye et al, 2016; Jun et al., 2015; Shao et al., 2014). Hubungan yang kuat antara kadar total penol dengan aktivitas antioksidan ditemukan pada beras hitam dimana pada beras ini asam ferulat diketahui sebagai senyawa fenolik yang utama (Jun et al., 2015). Beras putih memiliki kadar total fenol yang lebih rendah dibandingkan dengan beras merah dan aktivitas antioksidan beras tersebut berbanding lurus dengan kadar total fenolnya (Shao et al., 2014). Pada penelitian ini, peningkatan kadar total fenol nasi akibat penambahan campuran kunyit atau kayu manis yang tidak signifikan (Figur 3) diduga menjadi penyebab mengapa aktivitas antioksidan nasi yang dimasak dengan campuran kunyit dan kayu manis tidak berbeda dengan nasi biasa.

\section{Total Fenol Nasi}

Hasil analisis menunjukan bahwa campuran kunyit dan kayu manis tidak berpengaruh nyata terhadap total fenol nasi. Total fenol nasi yang dimasak tanpa atau dengan penambahan campuran kunyit dan kayu manis berkisar antara 99,419 (C5) hingga 119,031 (C4) ppm (GAE) (Figur 3). Penggunaan campuran kunyit dan kayu manis pada pemasakan nasi hanya meningkatkan kadar total penol nasi maksimal sebesar $19,1 \mathrm{ppm}$, yaitu pada nasi yang dimasak dengan penambahan $3 \mathrm{~g}$ kayu manis (C4).

Kandungan senyawa penolik pada beras tergantung pada varietas padinya (Tian et al., 2004; total penol beras putih berkisar antara 14,6-33,4 ppm, beras merah 66,8-422,2 ppm, dan beras hitam antara 56,8-82,0 ppm (Shao et al., 2014). Pemasakan dapat menyebabkan penurunan kadar total penolik beras dan juga mempengaruhi perbandingan antara senyawa penolik larut dan tak larut (Massaretto et al., 2011). Pada penelitian ini kadar total penolik nasi yang sudah dikeringkan rata-rata sebesar 99,4 ppm.

Untuk menguji apakah tingkat hidrolisis pati dan aktivitas antioksidan nasi tergantung pada kadar total penol maka dilakukan analisis korelasi Pearson (Tabel 1). Seperti disebutkan dibagian awal pembahasan bahwa senyawa penolik memiliki aktivitas penghambatan terhadap enzim alpha amilase (Kalita et al., 2018; Marmouzi et al., 2017; Gondi dan Prasada, 2015) dan juga menentukan aktivitas antioksidan beras/nasi (Ye et al, 2016; Jun et al., 2015; Shao et al., 2014). Tetapi hasil penelitian ini tidak mendukung antioksidan nasi yang dihasilkan (Figur 2). Aktivitas Goufo dan Trindade, 2014; Shao et al., 2014). Kadar 
Tabel 1. Hubungan antara kadar total penol dengan daya cerna pati dan aktivitas antioksidan nasi

\begin{tabular}{|c|c|c|c|}
\hline \multicolumn{2}{|c|}{ Parameter pengamatan } & Tingkat hidrolisis pati & Antioksidan \\
\hline \multirow[t]{2}{*}{ Antioksidan } & Pearson correlation & $-0,289$ & \\
\hline & P-Value & 0,296 & \\
\hline \multirow[t]{2}{*}{ Total penol } & Pearson correlation & $-0,119$ & $-0,190$ \\
\hline & P-Value & 0,672 & 0,497 \\
\hline
\end{tabular}

Tabel 2. Pengaruh komposisi rempah yang digunakan dalam pemasakan nasi terhadap respon hedonik nasi.

\begin{tabular}{lcccc}
\hline Parameter & \multicolumn{4}{c}{ Komposisi rempah dalam campuran } \\
\cline { 2 - 5 } organoleptik & $\mathrm{C} 4$ & $\mathrm{C} 3$ & $\mathrm{C} 2$ & $\mathrm{C} 1$ \\
\hline Rasa & $3,42^{\mathrm{b}}$ & $3,50^{\mathrm{b}}$ & $3,81^{\mathrm{a}}$ & $3,74^{\mathrm{a}}$ \\
Aroma & $3,33^{\mathrm{b}}$ & $3,48^{\mathrm{ab}}$ & $3,68^{\mathrm{a}}$ & $3,65^{\mathrm{a}}$ \\
Kepulenan & $3,60^{\mathrm{b}}$ & $3,68^{\mathrm{ab}}$ & $3,81^{\mathrm{a}}$ & $3,81^{\mathrm{a}}$ \\
Warna & $3,43^{\mathrm{b}}$ & $3,37^{\mathrm{b}}$ & $3,86^{\mathrm{a}}$ & $3,81^{\mathrm{a}}$ \\
\hline
\end{tabular}

Keterangan:C1 = 3 gram kunyit. 0 gram kayu manis; C2 = 2 gram kunyit, 1 gram kayu manis; C3 = 1 gram kunyit, 2 gram kayu manis; C4 = 0 gram kunyit, 3 gram kayu manis; C5 = control. Respon konsumen : $1=$ sangat tidak layak; 2 = tidak layak; $3=$ kurang layak; $4=$ layak; $5=$ sangat layak

berbagai penelitian tersebut. Kadar total penol tidak berhubungan dengan derajat hidrolisis pati $(p=0,296)$ dan aktivitas antioksidan $(p=0,497)$. Kadar total penol yang tidak berbeda nyata antara perlakuan diduga menjadi penyebab mengapa hubungan antara kadar total penol dengan derajat hidrolisis pati atau antioksidan tidak teramati.

\section{Penerimaan Konsumen}

Penggunaan rempah-rampah pada pemasakan nasi diduga dapat mengubah karakteristik sensori dari nasi yang dihasilkan. Karena campuran rempah dan herbal yang dihasilkan penelitian ini diharapkan dapat menjadi bagian gaya hidup khususnya pola makan, maka perubahan yang dihasilkan diharapkan tidak menurunkan tingkat penerimaan nasi yang dihasilkan sebagai makanan pokok. Masyarakat sudah terbiasa dengan nasi putih yang pemasakannya tidak menggunakan campuran rempah atau herbal, sehingga pada penelitian ini, nasi yang dihasilkan dari pemasakan menggunakan campuran rempah-rempah di uji kelayakannya sebagai makanan pokok yang akan menggantikan nasi putih.

Hasil penelitian menunjukkan bahwa penggunaan rempah-rempah dalam pemasakan nasi menghasilkan persepsi panelis yang berbeda-beda tergantung campuran yang digunakan (Tabel 2). Nasi yang dimasak menggunakan campuran $100 \%$ kayu manis (C4) memiliki tingkat kelayakan rasa, aroma, kepulenan dan warna yang lebih rendah dibandingkan nasi yang dimasak dengan campuran $2 \mathrm{~g}$ kunyit dan $1 \mathrm{~g}$ kayu manis (C2) atau 100 kunyit (C1). Penggunaan campuran 2 g kunyit dan $1 \mathrm{~g}$ kayu manis (C2) cenderung menghasilkan tingkat kelayakan tertinggi dibandingkan campuran yang lain dan nasi ini dapat dikategorikan layak sebagai makanan pokok.

Selain diminta menilai kelayakan nasi yang dihasilkan dengan pemasakan menggunakan campuran rempah-rempah, panelis juga diminta mengurutkan tingkat kelayakan nasi sebagai makanan pokok yang dimasak dengan campuran rempah-rempah dengan komposisi yang berbeda. Peringkat terbaik memiliki nilai 1 dan dianggap paling layak sebagai makanan pokok, dan peringkat terburuk adalah 4 dan dianggap paling tidak layak sebagai makanan pokok. Walaupun tidak ada jenis campuran rempah yang menghasilkan nasi dengan peringkat satu tetapi diketahui bahwa penggunaan campuran $2 \mathrm{~g}$ kunyit dan $1 \mathrm{~g}$ kayu manis (C2) atau 100 \% kunyit (C1) memiliki peringkat yang lebih baik dibandingkan dengan nasi yang dimasak dengan campuran yang lainnya (Figur 4).

Data penelitian ini menunjukkan bahwa penggunaan campuran rempah dan komposisinya tidak berpengaruh terhadap daya cerna pati dan aktivitas antioksidan nasi yang dihasilkan. Data juga menunjukkan bahwa komposisi campuran rempah menghasilkan tingkat kelayakan sebagai makanan pokok yang berbeda menurut konsumen. Penggunaan 2 g kunyit dan $1 \mathrm{~g}$ kayu manis (C2) atau 100\% kunyit (C1) lebih layak jika dibandingkan dengan penggunaan $100 \%$ kayu manis (C4) atau campuran $1 \mathrm{~g}$ kunyit dan $2 \mathrm{~g}$ kayu manis (C3). Karena itu C2 dan C1 merupakan formula yang bisa dipilih untuk dikembangkan lebih lanjut. Penggunaan campuran rempah-rempah diduga akan memberi manfaat lebih dibandingkan jika menggunakan rempah-rempah tunggal. Karena itu untuk penelitian selanjutnya formula $\mathrm{C} 2$ dipilih untuk diuji respon glikemiknya.

\section{Respon Glikemik Nasi}

Pengukuran respon glikemik dilakukan terhadap nasi biasa (kontrol) dan nasi yang dimasak dengan penambahan formula C2. Formula C2 adalah perlakuan terbaik berdasarkan analisis penerimaan konsumen dan mengandung campuran kunyit dan kayu manis. Perubahan kadar gula rata-rata responden setelah mengonsumsi nasi biasa dan nasi yang dimasak dengan penambahan formula C2 dapat dilihat pada Figur 5.

Kadar glukosa rata-rata responden setelah 30 menit mengonsumsi nasi biasa (kontrol) sebesar 105,3 $\mathrm{mg} / \mathrm{dl}$ dan untuk nasi dengan penambahan formula $\mathrm{C2}$ sebesar 116,2 mg/dl. Figur 5 juga menunjukkan bahwa penyerapan gula maksimal dalam darah terjadi pada 30 menit pertama setelah mengonsumsi pangan uji.

Luas area di bawah kurva (LADK) kadar darah responden setelah mengonsumsi nasi dapat dilihat pada Figur 6. Hasil uji t menunjukkan bahwa tidak terdapat perbedaan yang signifikan $(p=0,326)$ antara LADK 
kedua nasi yang diuji (10947 unit untuk nasi biasa dan 11268 unit untuk dengan penambahan formula C2) dan hasil ini sejalan dengan hasil uji tingkat hidrolisis yang menunjukkan bahwa tidak terdapat perbedaan tingkat hidrolisis pati nasi biasa dengan nasi yang dimasak dengan formula C2 (Figur 1).

Figur 7 memberikan penjelasan mengapa perbedaan LADK kedua jenis nasi yang diuji tidak berbeda nyata yaitu bahwa ragam data sangat tinggi sehingga walaupun nasi yang dimasak dengan formula C2 memiliki LADK lebih tinggi (11268 unit) dibandingkan nasi biasa (10947 unit), namun perbedaan ini tidak signifikan. Masing-masing nasi memiliki LADK yang bervarisi tergantung pada respondennya.

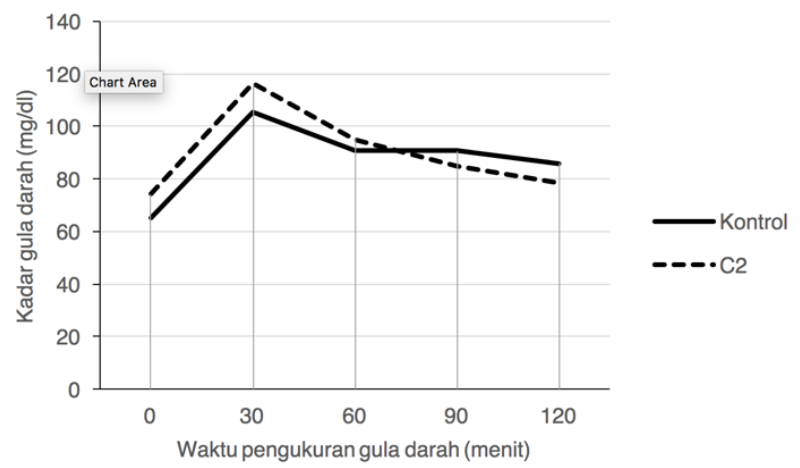

Figur 5. Respon glikemik rata-rata per waktu $(0,30,60,90,120$ menit) setelah mengonsumsi nasi biasa (kontrol) dan perlakuan C2. Nilai tengah yang diperoleh berdasarkan perhitungan dari 10 responden

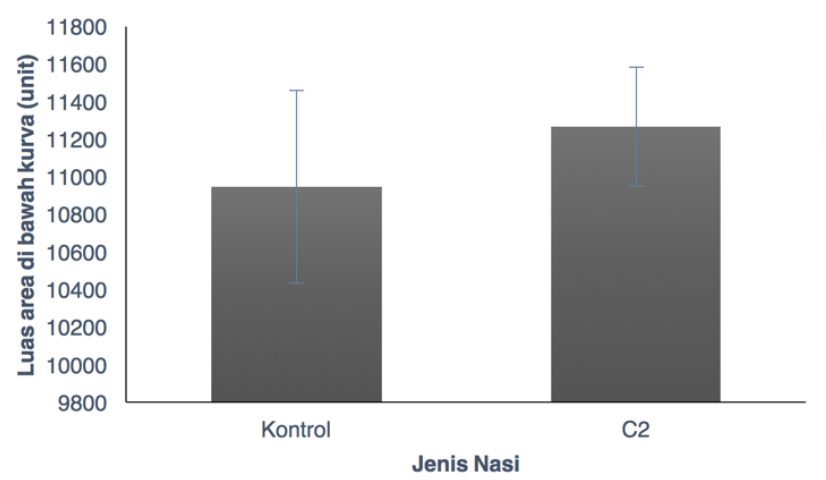

Figur 6. Luas area di bawah kurva gula darah setelah mengonsumsi nasi biasa (Kontrol) atau nasi yang dimasak dengan penambahan formula $\mathrm{C} 2$

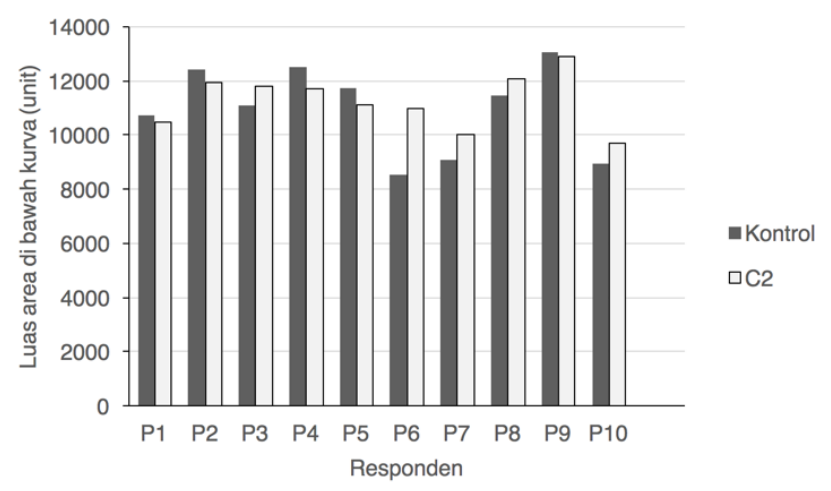

Figur 7. Luas area dibawah kurva nasi biasa (kontrol) atau atau nasi yang dimasak dengan penambahan formula C2 (C2) masing-masing responden

Peningkatan kadar gula darah sebagai respon terhadap konsumsi suatu jenis pangan bersifat individual (Vrolix dan Mensink, 2010). Suatu jenis makanan yang sama dan dalam jumlah yang sama jika dikonsumsi oleh subjek yang berbeda akan menghasilkan kenaikan kadar gula darah yang berbeda. Hirsch et al. (2013) melaporkan bahwa konsumsi roti putih oleh 10 subjek yang sehat menghasilkan nilai LADK beragam dengan variasi rata-rata 51,8\%. Keragaman ini antara lain dipengaruhi beberapa faktor yang tidak menjadi kriteria seleksi responden seperti indeks insulin dan kadar hemoglobin terglikasi (Matthan et al., 2016).

\section{Kesimpulan}

Formulasi campuran kunyit dan kayu manis tidak dapat menurunkan daya cerna pati nasi in vitro atau meningkatkan aktivitas antioksidan nasi yang dihasilkan karena penggunaan campuran rempah tersebut tidak dapat meningkatkan total fenol nasi yang dihasilkan. Nasi yang dimasak menggunakan campuran $2 \mathrm{~g}$ kunyit dan $1 \mathrm{~g}$ kayu manis dianggap layak oleh panelis sebagai makanan pokok tetapi nasi ini memiliki respon glikemik yang tidak berbeda dengan nasi biasa.

\section{Ucapan Terima kasih}

Penelitian ini didanai oleh Kementrrian Riset, Teknologi dan Pendidikan Tinggi (Kemenristekdikti) melalui Program Penelitian Terapan tahun 2017-2018.

\section{Daftar Pustaka}

Anderson, J.W. 2006. Diabetes mellitus: medical nutrition therapy. In Modern Nutrition in Health and Disease Tenth Edition. Shils ME (Ed.). Lippincott Williams \& Wilkins.Philadelpia. Page 1043-1066.

El, S.N. 1999. Determination of glicemic index for some breads. Journal of Food Chemistry 67(1):67-69. DOI: 10.1016/S0308-8146(98)00262-3

Dyson $\mathrm{P}$. Low carbohydrate diets and type 2 diabetes: What is the latest evidence? Diabetes Theraphy 6(4):411-424. DOI: 10.1007/s13300-015-0136-9

Ghosh, S., Chowdhury, S., Sarkar, P., Sil, P.C. 2018. Ameliorative role of ferulic acid against diabetes associated oxidative stress induced spleen damage. Food Chemistry Toxicology 118:272286. DOI: 10.1016/j.fct.2018.05.029.

Gondi, M., Prasada Rao, U.J. 2015. Ethanol extract of mango (Mangifera indica L.) peel inhibits aamylase and a-glucosidase activities, and ameliorates diabetes related biochemical parameters in streptozotocin (STZ)-induced diabetic rats. Journal Food Science Technology 52(12):7883-93. DOI: 10.1007/s13197-015-19634.

Goufo, P., Trindade, H. 2014. Rice antioxidants: phenolic acids, flavonoids, anthocyanins, 
proanthocyanidins, tocopherols, tocotrienols, $\mathrm{Y}$ oryzanol, and phytic acid. Food Science Nutrition 2(2):75-104. DOI: 10.1002/fsn3.86.

Hirsch, S, Barrera, G., Leiva, L., de la Maza, M.P., Bunout, D. 2013. Variability of glycemic and insulin response to a standard meal, within and between healthy subjects. Nutr Hosp. 28(2):5414. DOI: 10.3305/nh.2013.28.2.6161.

Hu, E.A., Pan, A., Malik, V., Sun, Q. 2012. White rice consumption and risk of type 2 diabetes: Metaanaysis and systematic review. British Medical Journal 15 : 344-1454. DOI:10.1136/bmj.e1454.

Ismail, J., Runtuwene, M.R.J., Fatimah, F. 2012. Penentuan total fenolik dan uji aktivitas antioksidan pada biji dan kulit buah pinang Yaki (Areca vestiaria Giseke). Jurnal IImiah Sains 12(2):84-88. DOI: 10.1234/jis.v12i2.557

Jun, H.I., Shin, J.W., Song, G.S., Kim, Y.S. 2015. Isolation and identification of phenolic antioxidants in black rice bran. Journal Food Science 80(2):C262-8. DOI: 10.1111/1750-3841.12754.

Kalita, D., Holm, D.G., LaBarbera, D.V,, Petrash, J.M., Jayanty, S.S. 2018. Inhibition of a-glucosidase, aamylase, and aldose reductase by potato polyphenolic compounds. PLoS One 25;13(1):e0191025. DOI 10.1371/journal. pone.0191025.

Marmouzi, I., Karym, E.M., Saidi, N., Meddah, B., Kharbach, M., Masrar, A., Bouabdellah, M, Chabraoui, L., El Allali, K., Cherrah, Y., Faouzi, M.E.A. 2017. In vitro and in vivo antioxidant and anti-hyperglycemic activities of Moroccan Oat Cultivars. Antioxidants (Basel) 6;6(4). DOI: 10.3390/antiox6040102.

Massaretto, I.L,, Alves, M.F.M., de Mira, N.V.M., Carmona, A.K., Marquez, U.M.L. 2011. Phenolic compounds in raw and cooked rice (Oryza sativa L.) and their inhibitory effect on the activity of angiotensin l-converting enzyme. Journal of Cereal Science 54(2):236-240. DOI:10.1016/ j.jcs.2011.06.006.

Matthan, N.R, Ausman, L.M., Meng, H., Tighiouart, H., Lichtenstein, A.H. 2016. Estimating the reliability of glycemic index values and potential sources of methodological and biological variability. American Journal Clinical Nutrition104(4):10041013. DOI:10.3945/ajcn.116.137208.

Muchtadi, T.R. 1989. Teknologi Proses Pengolahan Pangan. PAU Pangan dan Gizi, IPB. Bogor.

Perez-Gregorio, M.R., Simal-Gandara, J. 2017. A Critical review of the characterization of polyphenolprotein interactions and their potential use for improving food quality. Current Pharmaceutical Design 23(19):2742-2753. DOI: 10.2174/ 1381612823666170202112530.

Polce, S.A., Burke, C., França, L.M., Kramer, B., de Andrade Paes, A.M., Carrillo-Sepulveda, M.A. 2018. Ellagic acid alleviates hepatic oxidative stress and insulin resistance in diabetic female rats. Nutrients10(5):531. DOI: 10.3390/ nu10050531.
Resurreccion, A. V. A. 1998. Consumer Sensory Testing For Product Development. An Aspen Publication Aspen Publishers, Inc. Gaithersburg, Maryland

Riccardi,G., Capaldo, B., Vaccaro, O. 2005. Functional foods in the management of obesity and type 2 diabetes. Current Opinion in Clinical Nutrition and Metabolic Care 8(6):630-5. DOI:10.1097/01.mco. 0000171126.98783.0c.

Shao, Y., Xu, F., Sun, X., Bao, J., Beta, T. 2014. Phenolic acids, anthocyanins, and antioxidant capacity in rice (Oryza sativa L.) grains at four stages of development after flowering. Food Chemistry 143:90-6. DOI: 10.1016/j.foodchem.2013.07.042.

Talaei B, Amouzegar A, Sahranavard S, Hedayati M, Mirmiran P, Azizi F. 2017. Effects of cinnamon consumption on glycemic indicators, advanced glycation end products, and antioxidant status in type 2 diabetic patients. Nutrients 9(9):E991. DOI: 10.3390/nu9090991

Tian, S., Nakamura, .K, Kayahara, H. 2004. Analysis of phenolic compounds in white rice, brown rice, and germinated brown rice. Journal of Agriculture Food Chemistry 52(15):4808-13. DOI:10.1021/ jf049446f

Vrolix, R., Mensink, R.P. 2010. Variability of the glycemic response to single food products in healthy subjects. Contempprary Clinical Trials 31(1):5-11. DOI: 10.1016/j.cct.2009.08.001.

Walter, M., Marchesan, E. 2011. Phenolic compounds and cntioxidant activity of rice. Brazilian Archives of Biology and Technology 54(2):371-377. DOI:10.1590/S1516-89132011000200020.

Wojcik, M., Krawczyk, M., Wojcik, P., Cypryk, K., Wozniak, L.A. 2018. Molecular mechanisms underlying curcumin-mediated therapeutic effects in type 2 diabetes and cancer. Oxidative Medicine and Cellular Longevity 2018:1-14. DOI: 10.1155/2018/9698258.

Ye, L., Zhou, S., Liu, L., Waters, D.L.E., Zhong, K., Zhou, X., Ma, X., Liu, X. 2016. Phenolic compounds and antioxidant capacity of brown rice in China. International Journal of Food Engineering 12(6):537-546. DOI: 10.1515/ijfe-2015-0346.

Zheng, J., Cheng, J., Zheng, S., Feng, Q., Xiao, X. 2018. Curcumin, a polyphenolic curcuminoid with its protective effects and molecular mechanisms in diabetes and diabetic cardiomyopathy. Frontier in Pharmacology 9:472. DOI: 10.3389/ fphar.2018.00472.

Zhu, F. 2015. Interactions between starch and phenolic compound. Trends in Food Science \& Technology 43:129-143. DOI:10.1016/j.tifs.2015.02.003. 